\title{
Strategies for Sustainable and Circular Management of Phosphorus in the Baltic Sea Region: The Holistic Approach of the InPhos Project
}

\author{
Marzena Smol ${ }^{1}$, Michał Preisner ${ }^{1}\left(\mathbb{D}\right.$, Augusto Bianchini $^{2, *} \mathbb{C}$, Jessica Rossi ${ }^{2}{ }^{(\mathbb{D}}$, \\ Ludwig Hermann ${ }^{3}{ }^{(1)}$, Tanja Schaaf ${ }^{4}$, Jolita Kruopiene ${ }^{5}$, Kastytis Pamakštys ${ }^{5}{ }^{(1)}$, \\ Maris Klavins ${ }^{6}{ }^{(D}$, Ruta Ozola-Davidane ${ }^{6}{ }^{D}$, Daina Kalnina ${ }^{7}$, Elina Strade ${ }^{7}$, \\ Viktoria Voronova ${ }^{8}$ D , Karin Pachel ${ }^{8}$, Xiaosheng Yang ${ }^{9}$, Britt-Marie Steenari ${ }^{10}$ and \\ Magdalena Svanström ${ }^{11}$ \\ 1 Mineral and Energy Economy Research Institute, Polish Academy of Sciences, ul. Wybickiego 7A, \\ 31-261 Cracow, Poland; smol@meeri.pl (M.S.); preisner@min-pan.krakow.pl (M.P.) \\ 2 Department of Industrial Engineering, University of Bologna, Via Fontanelle 40, 47121 Forlì, Italy; \\ jessica.rossi12@unibo.it \\ 3 Proman Management GmbH, Weingartenstrasse 92, 2214 Auersthal, Austria; 1.hermann@proman.pro \\ 4 Outotec GmbH \& Co KG, Ludwig-Erhard-Strasse 21, 61440 Oberursel, Germany; tanja.schaaf@outotec.com \\ 5 Institute of Environmental Engineering, Kaunas University of Technology, Gedimino g, 50, LT-44239 Kaunas, \\ Lithuania; jolita.kruopiene@ktu.lt (J.K.); kastytis.pamakstys@ktu.lt (K.P.) \\ 6 Department of Environmental Science, University of Latvia, Raina Blvd 19, LV-1586 Riga, Latvia; \\ maris.klavins@lu.lv (M.K.); ozola.ruuta@gmail.com (R.O.-D.) \\ 7 Institute of General Chemical Engineering, Faculty of Materials Science and Applied Chemistry, \\ Riga Technical University, Paula Valdena 3/7, LV-1048 Riga, Latvia; Daina.Kalnina@rtu.lv (D.K.); \\ Elina.Strade@rtu.lv (E.S.) \\ 8 Department of Civil Engineering and Architecture, Tallinn University of Technology, Ehitajate tee 5, \\ 19086 Tallinn, Estonia; Viktoria.voronova@ttu.ee (V.V.); karin.pachel@ttu.ee (K.P.) \\ 9 GTK Mintec, Geological Survey of Finland, Tutkijankatu 1, 83500 Outokumpu, Finland; jason.yang@gtk.fi \\ 10 Department of Chemistry and Chemical Engineering, Energy and Materials, Chalmers University of \\ Technology, 41296 Gothenburg, Sweden; bms@chalmers.se \\ 11 Department of Technology Mangement and Economics, Environmental Systems Analysis, Chalmers \\ University of Technology, 41296 Gothenburg, Sweden; magdalena.svanstrom@chalmers.se \\ * Correspondence: augusto.bianchini@unibo.it; Tel.: +39-0543-374438
}

Received: 26 February 2020; Accepted: 20 March 2020; Published: 24 March 2020

check for updates

\begin{abstract}
Despite the significant reduction of phosphorus (P) discharge in the Baltic Sea in the last decades, obtained through the implementation of some approaches within the Helsinki Convention, eutrophication is still considered the biggest problem for the Baltic Sea environment. Consequently, the reduction of $\mathrm{P}$ load is an urgent need to solve, but the complexity of both the environmental and legislative context of the area makes this process difficult (more than in the past). Eutrophication is an intricate issue requiring a proper framework of governance that is not easy to determine in the Baltic Sea Region where the needs of several different countries converge. To identify the most suitable strategy to reduce the eutrophication in the Baltic Sea, the InPhos project (no. 17022, 2018-2019, funded by the European Institute of Innovation \& Technology (EIT) Raw Materials) adopted a holistic approach considering technical, political, economic, environmental and social aspects of $\mathrm{P}$ management. With the aims to raise awareness about the $\mathrm{P}$ challenge, foster the dialogue among all the stakeholders, and find solutions already developed in other countries (such as Germany and Switzerland) to be transferred in the Baltic Sea Region, the InPhos project consortium applied the methodology proposed in this paper, consisting of three main phases: (i) analysis of the available technologies to remove $\mathrm{P}$ from waste streams that contribute to eutrophication; (ii) analysis of the main streams involving P in Baltic Sea countries to highlight the potential of more sustainable and
\end{abstract}


circular P management; (iii) study of the current context (e.g., already-existing initiatives and issues). This approach allowed us to identify four categories of recommendations and practical actions proposed to improve P management in the Baltic Sea region. During the project, the consortium mainly addressed social aspects. Following steps beyond the project will be more quantitative to determine the techno-economic feasibility of circular P management in selected demo cases in the region.

Keywords: phosphorus management; circular economy; Baltic Sea; eutrophication

\section{Introduction}

Phosphorus $(\mathrm{P})$ is a fundamental nutrient for the growth of all living organisms, with properties that cannot be replaced by any other element. In particular, P represents the third major macronutrient (after potash and nitrogen) that is used in industrially produced fertilizers. Consequently, P represents a crucial building block of the food security system. Regrettably, in practice, $\mathrm{P}$ is a non-renewable mineral resource since a time misbalance exists between the geological cycle of phosphorous-bearing minerals (million years) and the anthropic use cycle (daily-annual) [1-4]. Moreover, primary P mines are concentrated in a few areas (China, Morocco, USA), mostly not belonging to the EU, which imports more than $90 \%$ of its $\mathrm{P}$ demand. This context, characterized by quantity and quality scarcity of primary $\mathrm{P}$, increasing demand and high price volatility of $\mathrm{P}$ fertilizers, represents a serious " $\mathrm{P}$ challenge" for the global economy and for the EU [5-7]. Issues of sustainable P management have been included in European policy since 2013, when the first communication directly related to P management, entitled "Consultative Communication on the Sustainable Use of Phosphorus", was published [8]. The main objective of this document was to start the development of a more rational and sustainable use of phosphorus from both primary and secondary sources. This initiative was also highlighted in the "Roadmap to a Resource-Efficient Europe" [9]. Management of the phosphorus raw materials increased in importance when, in 2014, phosphate rock was identified as a critical raw material (CRM) for the EU economy [10]. On the updated CRMs list, issued in 2017, next to phosphate rock, elementary phosphorus was also indicated [11]. The inclusion of $\mathrm{P}$ raw materials on the list indicates their extraordinary importance for the European economy and is intended to stimulate actions that can contribute to better management of phosphorus compounds from policy-makers, food, fertilizer and agricultural industries, farmers and scientists.

The phosphorous that enters the utilization chains in society is not entirely utilized in agriculture, breeding of animals, industrial food production, and neither is it in final human consumption. Only $15 \%$ of the total mineral P used in the food production sector is effectively consumed by humans. Even though there are losses of phosphorous in mining and fertilizer manufacturing, the greatest losses are associated with crop cultivation, meat, and dairy production. Along the food value chain, the main "waste" streams, are (in order of importance for the EU) (i) animal manure; (ii) urban wastewater and sewage sludge; and (iii) food processing (involving slaughter and other solid waste and food processing wastewater) [1,5]. These streams constitute a great loss of money and food production capacity. Moreover, when they are discharged into neighboring ecosystems, the effect of the nutrient can cause negative environmental issues, such as water body eutrophication [12-15]. Several coastal areas in the world are affected by eutrophication: in [16], 415 coastal systems were defined as eutrophic and hypoxic worldwide. Among them, the most critical are mainly the following five: the Baltic Sea, the North Sea, The Gulf of Mexico, the Chesapeake Bay, and the Black Sea [17]. Moreover, the eutrophication issue also continues to be pervasive in numerous lakes and rivers in the world. Between the 1970s and the 1990s, the strategies implemented to reduce the problem focused on a drastic decrease of the industrial and domestic $P$ sources, with actions such as the improvement of wastewater treatment and the banning of $\mathrm{P}$ in detergents. These measures improved the situation in some areas, such as 
Lake Erie (USA) and Lake Geneva (France) [18]. Starting from the beginning of 20th century, different types of strategies were proposed and introduced to address also other sources of P [19]. In [20], the strategies adopted by different areas affected by eutrophication were collected and sorted in clear categories, that can be summarized in (i) legal strategies: regulatory standards for nutrient pollution control, regulatory limits and caps, policies for ecosystem protection and restoration; (ii) technical strategies: research, monitoring and evaluation; (iii) financial strategies: economic and fiscal incentives; and (iv) social strategies: education and outreach, actions to strengthen institution and capacity to reduce nutrient pollution. In [21], a chronological list of laws and legal actions to improve water quality in Japan was provided. In European countries, from a legal point of view, stringent regulations about nutrient emissions to soil and water have been issued to avoid this type of environmental issue. Particularly, specific EU Directives (Nitrates Dir. (91/676/EEC), Sewage Sludge Dir. (86/278/ECC), Urban Waste Water Treatment Dir. (91/271/EEC), Industrial Emissions Dir. (2010/75/EU), and Water Framework Dir. (2000/60/EC) set some specific targets about nutrient contents in "waste" streams to obtain and/or maintain water bodies with a suitable ecological status. Since eutrophication impacts the environment, the economy, and human health (the three pillars of the sustainability), it derives that all these types of strategies and actions are intercorrelated and have to be supported by a suitable legislative framework [19].

The Baltic Sea region was one of the first marine areas to require an urgent solution for eutrophication (in the 1970s), but eutrophication is still considered the biggest problem for the Baltic Sea environment. Despite significant reductions on P discharge since the 1970s (above all from Poland [22]), obtained through the test of some approaches within the Helsinki Commission (HELCOM), signed by all the Baltic Sea coastal States, the P load in the Baltic Sea is still high and needs to be further reduced [23]. Decreasing the actual value of P load in the Baltic Sea, to respect the HELCOM targets, is more difficult than in the past. The greatest sources of P pollution are mainly diffuse-sources, related to agricultural activities and animal production, difficult to reduce and to trace. On the other hand, $P$ point-sources (the second category of $P$ pollution sources, e.g., urban and industrial waste-water) are simpler to divert, since they are concentrated and usually monitored. From the regulatory perspective, the difficulties derive from the complex regulatory settings, characterized by inter-connected, over-lapping levels of regulations and flexible legal approaches [24-27]. From the circular economy perspective, it is recommended to keep this raw material in the value chain (as wastewater and its fractions such as sewage sludge and ash from sewage sludge incineration, and other waste streams) for as long as possible, and to further recover and reuse valuable resources, including P. This could contribute to both eutrophication prevention and raw materials supply security [28]. Unfortunately, due to a lack of legal and economic drivers, nutrient recovery is still not a common solution, while P recovery, as well as energy efficiency, are among the main current challenges in wastewater treatment plant (WWTP) design and operation [29]. To select the most suitable strategy to improve this situation, multi-dimensional and transdisciplinary knowledge is needed. This means that expertise from different disciplines and all the stakeholders need to be integrated to create an understanding of the entire P supply chain, considering both the scientific and technical aspects and the social and economic implications [30,31].

With this holistic approach, the InPhos project no. 17022 (2018-2019), funded by the EIT Raw Materials, aims to develop a P long-term management strategy for the Baltic region, laying out a solid foundation for sustainable management of this critical raw material. The project considers the technical, political, economic, environmental and social aspects of the $\mathrm{P}$ cycle to (i) raise awareness about the urgent problem of $\mathrm{P}$ sustainability; (ii) foster dialogue among multi-disciplinary practitioners (e.g., policy makers and industries), the scientific and research community, and wider society on the consequences of P scarcity in Europe; and (iii) identify prospective solutions that can be implemented in the Baltic region to effectively reduce eutrophication. These objectives were addressed by a consortium of 12 European partners composed of 3 research Institutes and agencies (MEERI-Poland; GTK-Finland; BAM-Germany); 6 universities (KTU-Lithuania; TTU-Estonia; LU and RTU-Latvia; Chalmers 
TU-Sweden; UNIBO-Italy); 3 companies and utilities (OUTOTEC-Germany; BIONOR-Poland; Kauno vandenys-Lithuania). It created an interdisciplinary research team from each part of the knowledge triangle in order to effectively cover a wide range of complementary knowledge, expertise, and experiences of the $\mathrm{P}$ life-cycle and to make the project results relevant on the regional, national, and international levels. Recognizing the need for strategic cooperation at the European level, the partners joined forces to not only communicate the complexity of the "P challenge", but also to collect information on opportunities for more effective utilization of $\mathrm{P}$ from waste and other P-rich streams in the Baltic region.

\section{Materials and Methods}

With the aims of defining specific recommendations to find effective solutions to take decisive steps to reduce the eutrophication issue in the Baltic region and, where possible, to initiate well-functioning circular initiatives in P management, the methodology adopted during the InPhos project consisted of three main phases, as shown in Figure 1:

(i) Create an overview of the current P management in the Baltic countries, considering the main P flows (quantity and forms) in terms of $\mathrm{P}$ extraction, production, consumption, and losses to the environment (land and water bodies) to highlight the potential of improvement in P recovery;

(ii) Collect knowledge of the available technologies to remove and recover P from waste streams and options for selecting the most suitable solutions;

(iii) With a holistic approach, create an understanding of the main limitations for the implementation of $P$ removal technologies in relation to existing initiatives both on the national and European levels.

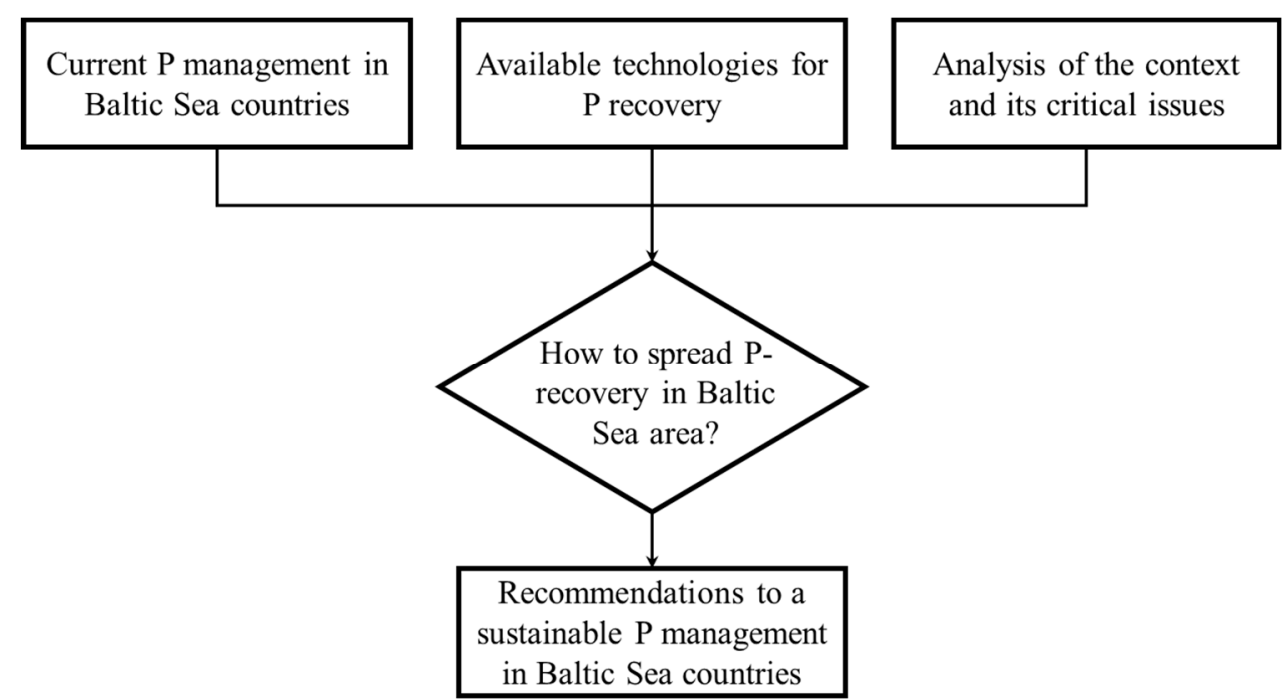

Figure 1. Flowchart of the methodology used in the InPhos project and in this study.

\subsection{P sources, Use and Management in the Baltic Sea Region}

The Baltic Sea in Northern Europe is surrounded by nine countries (Figure 2). Of them, Lithuania, Latvia, and Estonia are entirely within the Baltic Sea drainage area. Nevertheless, the largest Baltic sea drainage area territories belong to Sweden ( $25.6 \%$ of the overall drainage area), Russia $(18.3 \%)$, Poland (18.1\%), and Finland (17.5\%). Countries in the Baltic Sea region are classified as developed [32]. The region has a big population (about 85 million inhabitants) and is heavily industrialized, with intensive agriculture [33]. 


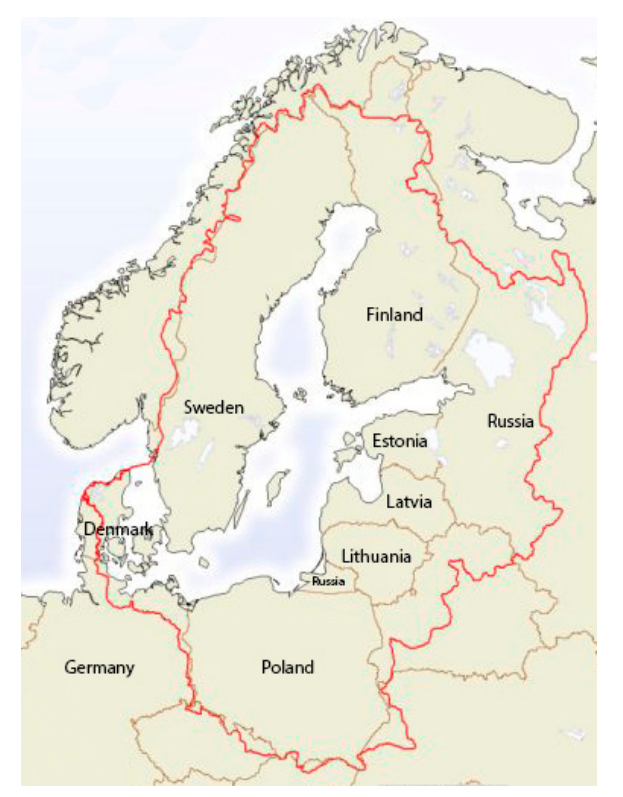

Figure 2. The Baltic Sea drainage area and countries of the Baltic region.

The characteristics of the Baltic sea make it a vulnerable ecosystem. It is a sheltered epicontinental sea with an average depth of only $52 \mathrm{~m}$ and a very limited water exchange. The Baltic Sea is one of the largest brackish waters in the world, with salinity in the ranges of $2 \%-20 \%$. Thus, the ecosystem tends to be strongly responsive to the effects of human activity and affected by pollution, including high levels of eutrophication due to the discharge of nutrients.

To boost the installation of P-recovery technologies in the Baltic Sea area and to select the most suitable solution, information about $\mathrm{P}$ production, consumption, losses, and dispersion of $\mathrm{P}$ were collected for Baltic Sea countries among the EU. This stage of the methodological approach required numerous efforts due to the fragmentation (in formats and in time) of available data for each Baltic Sea country. However, a great effort was applied to find, homogenize, and integrate them in a paper that considered the entire Baltic Sea region.

\subsubsection{Primary Sources of Phosphorus}

Russia was not within the scope of the in-depth analysis because its situation is different from that of EU member states: EU strategic and legal requirements apply only to member states, and phosphate rock is a critical raw material for EU countries. However, Russian phosphate rock resources, though not all in the Baltic Sea drainage area, are significant enough to be mentioned. Russia had $2 \%$ or 1.3 billion tonnes of globally known reserves of phosphate rock in 2015. Production of phosphate rock in Russia constituted 5\% of global mine production, the average for 2010-2014 [34].

Finland is unique in Western Europe for its phosphate rock resources, being the only EU member state where these resources are extracted ( $0.4 \%$ of global production [34]). The reported resources amount to 2360 million tonnes, with an average $4.0 \%$ phosphorus $\left(\mathrm{P}_{2} \mathrm{O}_{5}\right)$ content $[35,36]$. Finnish phosphorus resources are magmatic. Compared to sedimentary deposits, these have lower heavy metal concentrations. The largest known phosphate rock deposit, in terms of volume, is Siilinjärvi. It was discovered in 1950; quarrying began in 1979. On average, the ore consists of apatite $(10 \%)$, phlogopite ( $65 \%)$, carbonate (20\%, 4/5 calcite), and richterite (5\%). Siilinjärvi is Europe's only operating phosphate mine (operated by the Yara company) and processing plant. About 10 million tonnes of apatite ore are mined each year, producing about 1.0 million tonnes of apatite concentrate, which corresponds to about 375,000 tonnes of $\mathrm{P}_{2} \mathrm{O}_{5}$. It is further used in the production of phosphoric acid and phosphate fertilizers. The other significant deposit is Sokli. Known but not utilized reserves are concentrated in the gabbros of Southern Ostrobothnia. Nevertheless, their phosphorus content is lower 
than the Finnish average, and there are no plans for their commercial use in the near future. Potentially, the most significant yet unexplored phosphorus resources are included in the Iivaara alkaline massif and in the carbonatitic ring dikes on the southern side of the Sokli complex.

Estonia has approximately $800 \mathrm{Mt}_{2} \mathrm{O}_{5}$ in unused sedimentary phosphate rock reserves containing $\mathrm{P}_{2} \mathrm{O}_{5}$ in the range of $6 \%$ to $20 \%[37,38]$. Currently, Estonian phosphate rock is not mined since there are a lot of technical and environmental problems. Historically, phosphate rock in Estonia has been mined only in one region near Maardu city. The mining started in 1922. A phosphate powder was produced and upgraded to superphosphate fertilizer [39]. During the years of operation (1922-1991), 25 million tonnes of phosphorite ore were extracted [38]. Mining ended in 1991 due to environmental problems and exhaustion of resources at that mine.

Currently, in Poland, there is no mining of phosphate rock. It is worth emphasizing, however, that phosphate rock (on average, 14\% $\mathrm{P}_{2} \mathrm{O}_{5}$ ) occurs in the sediment strip on the Radom-Iłża-Annopol-Gościeradów-Modliborzyce section in various types of sediments [40]. In the past, they were used to produce phosphate fertilizers. Mining started after World War I. The resources of the 10 deposits identified were 42.4 million tonnes of phosphorite $\left(7.35\right.$ million tonnes $\left.\mathrm{P}_{2} \mathrm{O}_{5}\right)$. At present, however, they are not exploited for economic reasons. The last exploited deposit in Chałupki was closed in 1961, and in Annopol in 1971. Nowadays, reserves do not satisfy the established quality parameters for maximum depth of deposit and for minimum contents of phosphorus. Even more, the deposits are irrigated, which would hinder the potential for exploitation, and various infrastructure objects such as roads, railways, and high-voltage lines run through them, reducing their availability for exploitation by up to $50 \%-80 \%$. Therefore, all phosphate rock deposits in 2006 were deleted from the national resource balance, and the domestic demand for phosphate rock raw materials is fully covered by imports [41].

In Sweden, there are also no P-containing deposits that are mined for their phosphorus content. However, considerable $\mathrm{P}$ amounts are present in apatite-containing ores that are mined for their iron content [42]. The phosphorus ends up in the mining waste. It has been estimated that about 1.5 million tonnes of $\mathrm{P}$ is currently stored in these waste deposits, and possibilities for its recovery have been discussed [43].

In Latvia, mineral deposits containing phosphorus are rare [44]. Very small amounts of phosphorus-containing minerals such as phosphorite and vivianite can be found mainly in the east and northeast parts of Latvia [45].

Denmark, Germany and Lithuania do not have primary sources of phosphorus, such as phosphate rocks.

\subsubsection{Production of Mineral Phosphorus Fertilizers}

Large production capacity of mineral P fertilizers in the Baltic Sea region has been developed in Poland and Lithuania. Their fertilizer industry produced about $4.2 \%$ and $1.7 \%$ of world phosphate fertilizers in 2017, respectively. Polish fertilizer industry ranked among 5 top producers for monoamonium phosphate, NPK fertilizers, and superphosphate, while Lithuanian was among the top 5 for diamonium phosphate [46]. The demand for phosphorus raw materials both in Poland and in Lithuania is satisfied entirely by imports. Import to Poland is mainly in the form of phosphate concentrates from Morocco (45\% in 2016), Senegal (24\%), Israel (15\%), Algeria (11\%), Togo (4\%), and other countries [47]. Import to Lithuania is mainly from Russia (about 65\%), as well as from South Africa, Morocco, and other countries [48].

Germany had a substantial production of phosphate-fertilizing products in the 1970s and 1980s. Today, only a small capacity remains at ICL Ludwigshafen [49].

\subsubsection{Use of Phosphorus and Its Recovery from Secondary Sources}

Although there are some industries that need phosphorus for its production, the main user of $\mathrm{P}$, apart from fertilizer production, in the Baltic Sea region is intensive agriculture, for which both mineral 
and organic fertilizers are used. Depending on regional and national practices and regulations, sewage sludge and other secondary P sources are also exploited in agriculture.

Mineral fertilizers. A comparison of the mineral $\mathrm{P}$ fertilizer consumption in countries of the Baltic Sea region is presented in Table 1 (based on [50]). Poland and Germany are the biggest consumers of mineral $\mathrm{P}$ fertilizers in the region.

Table 1. Consumption of mineral P fertilizers by agriculture [50].

\begin{tabular}{ccccc}
\hline Baltic Country & P fertilizer Consumption (k tonnes) & \multicolumn{2}{c}{$\begin{array}{c}\text { Specific P Fertiliser Consumption } \\
\text { (tonnes/ha of Utilised Agricultural Area) }\end{array}$} \\
\hline Year & 2007 & 2017 & 2007 & 2017 \\
\hline Denmark & 14.0 & 20.8 & 5.6 & 8.1 \\
\hline Estonia & 3.5 & 4.1 & 3.9 & 4.2 \\
\hline Germany & 115.5 & 100.9 & 7.1 & 6.2 \\
\hline Finland & 16.0 & 12.3 & 8.0 & 6.1 \\
\hline Latvia & 7.3 & 11.3 & 5.9 & 7.7 \\
\hline Lithuania & 17.0 & 23.5 & 6.6 & 8.3 \\
\hline Poland & 179.9 & 150.0 & 12.0 & 10.7 \\
\hline Sweden & 13.7 & 14.5 & 4.9 & 5.2 \\
\hline
\end{tabular}

Organic fertilisers. The practice of using manure, slurry, or other organic fertilizers is common to a certain extent in all the countries. For instance, in Germany, some 200,000-240,000 annual tonnes of $\mathrm{P}$ are consumed by using livestock manure [51]. However, livestock manure-borne $\mathrm{P}$ is mainly used in regions with high livestock density due to the high water concentration in manure that hampers transportability. Consequently, by recycling P from manure in the form of concentrated, transportable fertilizing products, as demonstrated for instance by the H2020 project "SYSTEMIC" (www.systemicproject.eu), a yet unknown fraction of manure-borne P could be recycled to regions where P is needed and thus replace P from mineral fertilizers. Germany and Denmark have the largest numbers of livestock and, therefore, the largest amounts of manure and slurry to be spread on agricultural land. The livestock intensity (LSU/ha UAA = number of livestock units per hectare of utilised agricultural area) was1.09 LSU/ha UAA in Germany, and 1.58 LSU/ha UAA in Denmark in 2016 [52]. However, the manure in Denmark is currently not recycled in the most efficient way. The utilization of hosphorus from manure is indirectly limited due to the threshold imposed for nitrogen, that is, 140-170 kg N/ha/year for the entire Denmark [53]. Moreover, due to geographical conditions, the relocation of animal manure from farms with manure surplus to farms where it can substitute mineral $P$ fertilizer is critical since the large volumes of the resource reduce possible transport distances, just as in Germany. For improving P use efficiency from manure, current regulations, economic incentives, and technical solutions will be crucial. The lowest livestock intensity is reported in Lithuania (0.29 LSU/ha UAA), Estonia (0.28 LSU/ha UAA), and Latvia (0.26 LSU/ha UAA) [52]. Nevertheless, over-fertilization of fields belonging to intensive livestock farms happens in all the countries of the region [54].

Sewage sludge and other sources. The amount of produced sewage sludge, as one of the most important secondary resources for phosphorus, is indicated in Table 2 [55]. Sewage sludge treatment and utilization practices differ among countries.

Table 2. Sewage sludge production [55].

\begin{tabular}{ccccccccc}
\hline Country & Denmark & Estonia & Finland & Germany & Latvia & Lithuania & Poland & Sweden \\
\hline Year & 2010 & 2016 & 2015 & 2016 & 2017 & 2017 & 2017 & 2016 \\
\hline k tonnes dry matter $/$ year & 141,000 & 18,340 & 146,000 & $1,794,443$ & 24,940 & 42,488 & 584,454 & 204,300 \\
\hline
\end{tabular}


In Denmark, sewage sludge contains about $1590 \mathrm{t} / \mathrm{year}$ of P. Another important source of $\mathrm{P}$ is slaughterhouse waste (accounting for about 3000 tonnes of $\mathrm{P}$ for each year in Denmark). There are some success stories in the country regarding the recovery of phosphorus. For instance, the first full-scale demonstration plant, which intended to test the viability of secondary phosphate production, was opened by Aarhus Water treatment company in 2014. This plant is able to extract up to $50 \mathrm{~kg}$ $\mathrm{P} / \mathrm{day}$, which is $60 \%$ of the amount of phosphorus in the wastewater [56]. The largest phosphorus recovery plant was opened in 2015 by the Herning Water treatment company. The same technology was adopted at both plants: struvite is precipitated as a "ready-to-use fertilizer" and sold to a fertilizer company under the name PhosphorCare ${ }^{\mathrm{TM}}$. It obtained official approval as commercial fertilizer.

About 20,000 tonnes of dry matter sludge are produced in Estonia annually. In 2016, 84\% of the sewage sludge was used in landscaping and land restoration, $15 \%$ was landfilled, and a very small part of the sludge was used in agriculture. There are no obligatory regulations of $\mathrm{P}$ recovery from waste. The major alternative source of $P$ in Estonia is municipal and industrial wastewater and sewage sludge. However, a priority is the development and the inclusion of regulations connected with the treatment and recovery of valuable materials from these flows.

Finland produces approximately 140,000 tonnes of dry matter sewage sludge each year. There is no tradition to recycle nutrients from this sludge. Instead, $62 \%$ is used for landscaping and reforming of landfills, $33 \%$ is used for biogas production plants, $2 \%$ for landfill or final disposal, and $2 \%$ is used for agricultural soil amendments. One of the major reasons for this little percentage of sludge used as fertilizer is that people do not trust in sludge quality and do not want to cause human health and environmental problems because of organic pollutants and heavy metals that might be present in the sludge. Only 17 of WWTPs in Finland are large (>100,000 PE) [57]. Nevertheless, the Viikinmäki WWTP, located in Helsinki, with a capacity of around 270,000 cubic meters per day, is the largest wastewater treatment plant in Finland and the Nordic countries. Currently, there is no recovery of phosphorus [58,59]. Nevertheless, the construction of a demo plant for phosphorus recovery began at the Viikinmäki WWTP in 2018 [60]. Based on a survey conducted by the Finnish Innovation Fund Sitra on circular economy opportunities for Finland, the total amount of recyclable phosphorus was indicated to be 26,040 tonnes/year, of which 19,300 tonnes $(74.1 \%)$ came from livestock manure and 2880 tonnes $(11.1 \%)$ from municipal sewage sludge.

In Germany, about 1.76 million tonnes of dry matter sewage sludge (about 3\%-4\% P) with approximately 60,000 tonnes of $\mathrm{P}$ and 200,000 tonnes of Cat. 1 meat and bone meal (animal by-products, not for consumption, classified within 1 risk category according to Regulation (EC) 1069/2009) [61], with approximately 10,000 tonnes of $\mathrm{P}$, are available for P recycling. In 2017, about $68 \%$ of German sewage sludge was converted to energy in so-called mono-incineration plants, power plants, cement plants, and a few municipal solid waste incinerators, $17 \%$ applied to agricultural soils, and $13 \%$ used for "landscaping", among others, using sewage sludge as cover layer on the top of closed landfills. Due to the amendment of the Fertilising Ordinance in 2017, agricultural sludge use in Germany declined significantly. By this amendment, stricter requirements for nutrient management on cropland have been enforced in response to the high nitrate concentrations in German groundwater and non-compliance with the EU 1991 Nitrates Directive. The maximum annual amount of organic nitrogen has been limited to $170 \mathrm{~kg} \mathrm{~N}$ per hectare, regardless of being applied as manure or sewage sludge. Consequently, the competition of organic fertilizers for available cropland is increasing. Farmers prefer spreading their own manure and digestates to sewage sludge. Due to the significant decrease of sludge use in agriculture, a shortage of disposal capacities occurred. Therefore, there are plans to build up to 15 new incineration plants for sewage sludge [62]. P-recycling from ash is not yet implemented on a large scale, but several projects are underway; the first one will be commissioned in 2020/2021 in Hamburg. Several struvite plants are in operation in Germany; albeit, investment was not motivated by P-recycling but by OPEX (operational expenses) savings: avoidance of struvite scaling in pipes and reactors and lower sludge volumes due to enhanced dewaterability of sludge, the latter in processes 
applied to sewage sludge. Hence, struvite is considered a byproduct and not much attention is paid to its marketing and sales.

About 25,000 tonnes of dry matter sludge is produced in Latvia annually, $36 \%$ of which is produced in Riga. The content of P in sewage sludge obtained in different WWTPs in Latvia varies from 7.8 to $33 \mathrm{~g} / \mathrm{kg}$ dry sludge [63]. Sludge is mainly utilized in composting (27\% in 2016-2018) and in agriculture (16\% in 2016-2018) [64]. The annual emission limit value of total P derived from sewage sludge and compost in cultivated agricultural land is $40 \mathrm{~kg} / \mathrm{ha}$ [65]. In Latvia, sewage sludge is not completely used as a resource, which is confirmed by the fact that approximately $1 / 3$ of the sludge produced is temporarily stored in the areas of WWTPs unused [64]. The dispersed location of small-scale WWTPs limits centralized sludge management. There is no experience with P-recovery pilot plants in Latvia, and any legislation regulates the recovery of phosphorus from alternative phosphorus sources such as sewage sludge. Wastewater sludge is used in the reed canary grass and plantations of willow and fast-growing tree species on empty agriculture lands and to re-cultivate damaged areas (e.g., gravel and peat quarries) in different scales in Latvia $[66,67]$.

More than 40,000 tonnes of dry matter sludge are produced in Lithuania annually. In recent years, the amount of landfilled sludge has decreased. Instead, sludge usage for fertilization and compost production is increasing. In 2017, $48.3 \%$ of sewage sludge was used in agriculture, $38.7 \%$ for compost production, and $5.2 \%$ of sludge was treated by other means (e.g., granulation, drying) [68]. A small part $(0.3 \%)$ of the sludge was incinerated. There are digestion and drying facilities, also sludge composting sites. However, the development of the current wastewater sludge management infrastructure has not addressed the issue of the use of heat-dried and granular sludge, as there is no (mono)incineration capacity for it. Thus, a small percentage of sludge was incinerated in a municipal waste incinerator and in a cement kiln. In Lithuania, there is no legislation directly requiring recovery of phosphorus. Nevertheless, encouragement of such practices as composting allows the return of some $\mathrm{P}$ to the economic cycle.

In Poland, sewage sludge production was 1.035 million tonnes of dry matter in 2017. Of that, $56.5 \%$ originated from municipal WWTP and $43.5 \%$ from industrial WWTP [69]. The most frequently used methods of treatment were landfilling, use in agriculture, and incineration. However, the use of sewage sludge for applications in agriculture, in land reclamation, and in the cultivation of plants intended for the production of compost has gained no social acceptance, is seasonal, and there are not enough areas suitable for this purpose in the country. In recent years, 11 mono-incinerators for sewage sludge have been built next to large municipal WWTPs. The implemented phosphorus recycling solutions could be a good opportunity for Poland to decrease its dependency on imports of phosphate rock. However, there are no implemented $\mathrm{P}$ recycling technologies on the market. This is quite disturbing since a number of research teams have been working on the development and modernization of the technological solutions for efficient phosphorus recovery from waste, such as sewage sludge and sewage sludge ash [70]. Their achievements also include the integrated evaluation of the economic, technological and environmental aspects, in order to identify technologies and methods that are applicable and feasible alternatives to phosphate rock mining and mineral fertilizer production from that rock. Due to economic unprofitability, none of the Polish technologies have been implemented (they require large investment costs). Also, there are no legal requirements for nutrient recovery from waste streams in Poland. In 2018, the first investment in this area was started by the Jarocin Waterworks Company. It invested into the project "Modernisation and Extension of WWTP Jarocin" and is now building a station for the recovery of nutrients from sewage sludge.

Municipal wastewater treatment plants in Sweden receive about 5500 tonnes of phosphorus annually [71]. Most of the phosphorus (96\%) ends up in sewage sludge because many of the 1700 treatment plants operate with enhanced phosphorus removal. Looking at the statistics for the more recent years, about $25 \%$ of the sludge in Sweden has been used as a fertilizer in agriculture. There has been a debate among many different actors, e.g., food industry, farmers, the concerned public, and NGOs and governmental agencies over several decades in Sweden on potential risks related to 
sludge use in agriculture. This has led to the development of the REVAQ sludge certification system and to large ongoing efforts to reduce sludge pollution at the wastewater source, but also to several changes in the national sludge management policy over time. The Swedish government has recently commissioned an investigation that was reported in January 2020 [72], which suggested that sludge of high quality could be exempt from a ban on spreading in agriculture. Further, as the investigation report contains a suggestion of recovery of at least 60 percent of the phosphorus from sewage sludge of the public treatment plants of wastewater in excess of 20,000 p.e. (population equivalents), considerable changes to current sludge management could be required for plants with lower quality sludge or with longer distances to suitable agricultural land. It is unclear what consequences this will have in the foreseeable future.

\subsection{Technological Background for P Recovery: Field of Applications, Technical Features, and Output}

There are several waste streams that are promising sources for P recovery. The three most important waste streams are presented in Table 3.

Table 3. Waste streams identified as possible secondary P sources.

\begin{tabular}{cc}
\hline Sector & Secondary P Sources \\
\hline Agriculture & Manure [73,74]; Meat and bone meal [75]; Fish sludge [76,77] \\
\hline Municipal & $\begin{array}{c}\text { Municipal wastewater [78]; Municipal sewage sludge [79,80]; } \\
\text { Municipal sewage sludge ash [81,82]; Food waste [83] }\end{array}$ \\
\hline \multirow{2}{*}{ Industrial } & $\begin{array}{c}\text { Biomass ash [84]; Phosphogypsum [85]; Industrial wastewater [86] } \\
\text { Industrial sewage sludge [87]; Industrial sewage sludge ash [88] }\end{array}$ \\
\hline
\end{tabular}

The results of most recent research show that sewage sludge, food waste, and manure are the nutrient-rich secondary sources with the highest technical and economic potential for P extraction [28]. However, the greatest development of nutrients recovery methods was observed for sewage sludge and its processed forms. It is related to the fact that $90 \%$ of the phosphate load in sewage treatment plant influent is transferred to sewage sludge, as most recovery processes start after wastewater treatment. Currently, most technology providers pursue either integrated phosphate recovery from digested sludge or supernatant liquor or downstream phosphate recovery from sludge ash after mono-incineration. The first group refers to precipitation processes producing struvite or, in some applications, calcium phosphate. P-recycling from ash achieves much higher recovery rates. Technology suppliers offer wet chemical or thermal processes, the former extracting $\mathrm{P}$ by acid attack and the latter modifying the P-compounds to enhance the crop availability of $\mathrm{P}$ and to remove certain heavy metals. Some of the most advanced phosphate recovery processes have been included in a recent LCA study [89-92].

Essentially, five process approaches have been developed to pilot or full-scale applications: (i) precipitation of struvite (magnesium-ammonium-phosphate) from digested sludge; (ii) precipitation of struvite from the liquid fraction after sludge dewatering; (iii) acid attack of ash leaching phosphates with other compounds from ash after mono-incineration; (iv) thermal solubilization of phosphates in ash after mono-incineration with partial removal of heavy metals, and (v) replacement of phosphate rock by ash in conventional fertilizer manufacturing plants. Struvite precipitation is usually limited to enhanced biological phosphorus removal (EBPR) in wastewater treatment plants because chemical $P$ removal does not leave enough $P$ in solution to meaningful application of precipitation processes. The related business cases are built on improved dewaterability of sludge, reducing its volume and related disposal cost as well as on lower maintenance expenses for pumps and pipes due to avoiding unintended precipitation. P-recovery from ash after mono-incineration of sewage sludge must be re-financed by product sales and savings of ash disposal costs. Refinancing is quite challenging due to high volumes of leaching residues after the acid attack of ash and solid/liquid separation that must 
be either further treated for use in the building industry or landfilled. The comparatively low cost of ash disposal cannot generate enough savings to justify gate-fees covering a substantial part of the treatment cost, which always exceeds the cost of producing conventional phosphate fertilizers, mainly due to economy of scale effects. Thermal solubilization has the advantage of low waste generation ( $<3 \%$ of ash input) but $\mathrm{P}$ concentrations in the product do not exceed $\mathrm{P}$ concentrations in the ash and do not allow producing complex fertilizers of high demand in the market. The replacement of phosphate rock by ash in the fertilizer industry is a viable pathway to recycle ash to conventional products not distinguishable from rock-based fertilizers, but replacement is limited by the iron and aluminum concentrations in ash and, consequently, by a maximum amount of ash admixture that has not yet been determined. Mixing $5 \%-10 \%$ of ash to phosphate rock has been successfully tested.

Precipitation processes applied to sludge only recover $5 \%-15 \%$ of P. If similar processes are applied to sludge liquor (the liquid phase after dewatering), the maximum P-recovery rates may achieve $25 \%$ without upstream solubilization of $P$ and up to $40 \%$ with upstream solubilization by hydrolysis. The so-called Stuttgart process achieves even up to $50 \%$ recovery but with excessive chemical use as a downside. Processes recycling P from ash achieve $80 \%-100 \%$ recovery rates [89].

The predominant products of P-recovery methods are struvite or calcium phosphate, which can be obtained using chemical precipitation from the sludge dewatering liquors or raw wastewater with P concentration above $50 \mathrm{mg} / \mathrm{L}[92,93]$. Since a wide spectrum of P-recovery technologies is available, their selection should be guided by byproduct management possibilities and P-recovery efficiency. Moreover, the WWTP efficiency can be improved by P-recovery due to the added value in form of on-site fertilizer production and improved sludge dewatering, especially in plants using enhanced biological nutrient removal (EBPR) [94]. In addition, deliberate struvite precipitation can reduce the failure risk caused by blockage of pipes in the plant by uncontrolled precipitation of struvite crystals.

The appropriate selection of P-recovery technology for a specific situation is a complex task, which needs to include the indirect economic and environmental benefits or drawbacks. However, sewage sludge ash as the input for P-recovery seems to be the preferable pathway in terms of the recovery efficiency and the independence of sludge incineration plant and WWTP location. Japan has the largest concentration of P-recovery technologies: at least 16 full-scale plants were implemented to remove $P$ from waste streams and recover struvite and calcium phosphate [78]. It derives from a robust collaborative program on a national level, that activated an effective partnership between industry, high-level education and research, and government. In Europe, in 2019, there were 37 P-recovery plants based on various technologies. Germany and the Netherlands have the highest number of installed technologies, with 10 plants for each of them, followed by Belgium with 6 plants, and Denmark with 4 plants. France, Spain, and UK have 2 examples of installed P-recovery technologies, and Italy has 1 plant. In North America, 15 full-scale units are operating: these plants mainly produce struvite (Pearl and Airprex are typical installed technologies in this area) $[95,96]$. Only a limited amount of P-recovery technologies has been applied in the Baltic Sea region, mainly in Germany. In Poland, there is one installation for P recovery under construction in Cielcza [97]. In a few years, a wider implementation of P-recovery technologies is expected in the Baltic Sea area, mainly concerning waste streams from water and wastewater sectors.

\subsection{Analysis of the Context and Its Critical Issues}

Sustainable management of nutrients in the Baltic Sea area has been recognized as an urgent issue to solve for a number of years. Consequently, various initiatives have already taken steps in this direction, both at national and international levels. One of these is the European Union Strategy for the Baltic Sea region (2009). This strategy, which is the first developed on a macro-regional level in Europe, addresses the three key challenges in the region: (i) achievement of a safe sea, (ii) the need to connect the region, and (iii) improved prosperity. The objectives are complementary, and they relate to a wide range of policies. The European countries involved in this action plan are Denmark, Estonia, Finland, Germany, Latvia, Lithuania, Poland, and Sweden (analyzed in this paper), but it is also open 
for cooperation with EU-neighboring countries, such as Belarus, Iceland, Norway, and Russia. Still, at an international level, the EC periodically analyses and evaluates the methods with which all EU member states manage charging and monitoring systems on the effluents, considering the institutional responsibilities and the conditions to issue permits for effluent discharge directly into natural receivers. The EC also proposed a model calculation of effluent charges. In any case, there are still situations of illegal discharge of sewage, and failures in WWTPs in the Baltic Sea basin, which negatively affect its environment and accelerate eutrophication. Moreover, the obligatory recovery of $\mathrm{P}$ from selected waste streams (sewage sludge and sewage sludge ash) generated in the municipal WWTPs is adopted only in Germany and not in the other Baltic countries.

Other existing initiatives at international level aim to prevent the problem of $\mathrm{P}$ management in waste streams, incentivizing a sustainable consumption of nutrients. (i) The Farm Sustainability Tool for Nutrients (FaST), a tool of the Good Agricultural and Environmental Conditions (GAECs), aims to provide "elements" and "functionalities" to EU farmers for the sustainable use of fertilizers (in certain member states, direct payments are granted for planting cover crops between the seasons). (ii) The Horizon 2020 LEX4BIO project (www.lex4bio.eu): the expected result of this project is to provide a policy framework for the EU's transition to bio-based fertilizers (BBFs), while minimizing risks to the environment, protecting human health, and ensuring food safety and supply.

At the national level, since the EC asked all member states to develop CE action plans, some countries have already adopted some strategies and practices, such as in Finland, Germany, and Poland, and some of them are already available on the European Circular Economy Stakeholder Platform. However, these plans differ in detailed actions between countries. For example, in the Polish CE roadmap, it is mentioned that the wastewater sector is an important source of nutrients, which should be kept in the economy as long as possible, but there are no specific recommendations regarding the use of $\mathrm{P}$ in this document.

From a technical and technological point of view, further expert support for the EC is required in areas of P management. In this direction, the Horizon 2020 created financial support for many eco-innovation projects related to the recovery of raw materials, including phosphorus. In each of the Baltic Sea countries, there are also national funding programs which support the development of new technologies in the field of recovery of CRMs. In the 21st century, research and development (R\&D) activities are major driving forces behind higher productivity, quality, and innovation in the services and products offered by many organizations. Expenditures on R\&D are the largest in higher-income countries (Denmark, Germany, Sweden), which have the highest levels of the eco-innovation index. National funding programs already exist in Estonia: (i) the environmental investment center supports the implementation of environmental projects at a national level; (ii) the circular economy program supports activities that contribute to the more efficient usage of the resources (P-recovery program). In this context, many outstanding scientists have been working on P-recovery solutions for many years. For example, in Poland, among others, Cracow University of Technology and Wroclaw University of Technology developed innovative technologies to recover phosphorus from sewage sludge and sewage sludge ash. However, the developed technologies have not been implemented due to the lack of funds, and uncertain returns did not allow the commercialization of research results. Moreover, the economic evaluations showed that even with the financial support in the investment phase from the publicly available funds, the operation phase of such installations is not economically viable due to the high costs of recycled product in comparison to the commercial products (as fertilizers) from primary sources.

Consequently, as it was mentioned before, installations for $\mathrm{P}$ recovery from various waste streams exist in the Baltic Sea only in Denmark (4), Germany (10), and one under construction in Poland. Moreover, currently, both in the Baltic region and most other countries, the evaluation of environmental impacts of the new or modernized technologies (and of their products) is not mandatory. Providing robust impact information could contribute to the protection of the Baltic Sea from ongoing nutrient-derived pollution and make sure that the best environmental solution can be 
chosen. The provision of reliable and upgraded data is also fundamental for national and international statistics. Unfortunately, for many raw materials, including P resources, data about mass flows tend to be highly fragmented, lacking entirely, and collected using various methodologies in individual Baltic countries. Moreover, the reference points of data collected in many cases are unclear (provided in words only, not in the numbers), which result in ambiguous meaning and misinterpretation of the data.

\section{Results and Discussion}

Starting from the analysis of the available technologies for P removal from different waste streams and from the identification of the actual P management in the Baltic Region in relation to the current national and international contexts, the InPhos consortium have investigated the main reasons that prevented the installation of P-recovery technologies in countries in the Baltic Sea area.

The proposed methodological approach is mainly technical since it ensures the construction of a quantitative basis on which to define a common and shared strategy for the Baltic Sea area. In fact, without the identification of the main P flows in each country and without the knowledge of how they can be treated to recover $P$, it is difficult to highlight what are the priority and most valuable aspects to be addressed. A quantitative overview of the current P management in the Baltic Sea area would be useful for different stakeholders, in particular for (i) legislators and policy makers to estimate and select the most potential initiatives and strategies in this field; (ii) the scientific and technical community to improve technologies and/or widespread their applications; (iii) funding bodies to properly evaluate benefits and risks of an investment in this field; (iv) society to spread the awareness that solutions for the "P challenge" are urgently necessary.

The difficulties and the efforts in the construction of this quantitative basis allowed the identification of some critical factors. As a result, some recommended directions and relative practical actions are proposed to move towards widespread $P$ recovery from waste streams and, where possible, circular phosphorus management in the Baltic Sea region. In particular, for each of the four main areas identified as priorities (legislative, financial, technical, and social), some focal points are depicted, as shown in Table 4.

Summarizing all available information, there are several opportunities, but also barriers, for the implementation of strategies to improve phosphorus management in the Baltic Sea region. This requires systemic changes in people's awareness and their behavior, but also the development of innovation in technologies, financing methods, business models, and policies [98]. Activities of the InPhos project were mainly focused on the recommendations and the actions related to social aspects and to increase the awareness about the "P challenge". In particular, during the InPhos project, a close collaboration with all mentioned stakeholders (policymakers, industrial practitioners, high-education institutions, researchers, farmers, and citizens) was established. The coordinator and participants performed several awareness-raising activities (meetings and consultations), in the form of round-table and panel discussions, video-meetings, workshops and seminars in the countries taking part in the project: Estonia, Finland, Germany, Latvia, Lithuania, Poland, and Sweden (and also in Italy due to the participation of an Italian partner). All these activities helped to promote an interdisciplinary systems-thinking approach among stakeholders in the Baltic Sea region. In addition, several seminars and workshops have been organized as a part of the InPhos project to raise awareness of the importance of phosphorus. This initiative provided education tools about how to avoid food waste (rich in P resources) and how to choose the best regional food and feed supply (in order to support local farmers and minimize the cost of products). An important part of education content was to convince stakeholders to accept a fair price for quality food (role model: C'est qui, le patron; lamarqueduconsommateur.com). Moreover, education games and quizzes were developed and distributed among selected groups of stakeholders such as students, in order to interest future decision-makers in the topic of security of raw materials, including phosphorus. Finally, various dissemination activities were conducted, mainly related to the participation in national and international conferences and presentation of the project results in the form of oral speeches and posters. 
Table 4. Recommendations and practical actions for a more sustainable P management in the Baltic region, derived from InPhos project methodology.

\begin{tabular}{|c|c|c|}
\hline Category & Recommendations & Proposed Actions \\
\hline \multirow{5}{*}{$\begin{array}{l}\text { Legal } \\
\text { recommendations }\end{array}$} & $\begin{array}{l}\text { R1. Stricter requirements for more sustainable } \\
\text { consumption and production practices (involving } \\
\text { agriculture, food industries, water and wastewater } \\
\text { sector, phosphate and fertilizer industries). }\end{array}$ & $\begin{array}{l}\text { - Review of good agricultural practices and best available techniques for newly created or } \\
\text { modernized enterprises. } \\
\text { - Implementation of more effective control of farmers' practices (e.g., excessive spreading } \\
\text { of manure). } \\
\text { - Revision and further implementation of environmental charges, where the limit values } \\
\text { are significantly exceeded, for discharged municipal and industrial wastewater, and illegal } \\
\text { discharges to natural receivers. } \\
\text { - Alternative incentives/penalties, e.g., tax on effluents with nutrients, landfill tax, emission } \\
\text { taxes (methane, } \mathrm{N}_{2} \mathrm{O} \text {, ammonia). }\end{array}$ \\
\hline & $\begin{array}{l}\text { R2. Implementation of P-recovery regulations at } \\
\text { national level. }\end{array}$ & $\begin{array}{l}\text { Introduction of mandatory recovery of phosphorus from selected wastes to lead to an } \\
\text { extension of the life cycle of this element in the economy, and thus reduce the dependence on } \\
\text { imports and increasing raw material security for Europe. }\end{array}$ \\
\hline & $\begin{array}{l}\text { R3. Development of the national action plans for the } \\
\text { reuse of recovered P from selected waste streams. }\end{array}$ & $\begin{array}{l}\text { - According to the country's conditions and access to selected P-rich waste streams, it is } \\
\text { necessary to take into account all national recyclable P resources and the possibilities of their } \\
\text { recovery and reuse in all Baltic countries. } \\
\text { - Development of working group at national level in the Baltic Sea countries, who develops } \\
\text { the integrated P management system on national level. }\end{array}$ \\
\hline & $\begin{array}{l}\text { R4. Further work on the development of an integrated } \\
\text { management strategy for the Baltic Sea region } \\
\text { (including P). }\end{array}$ & Collaboration among working groups established at national level. \\
\hline & $\begin{array}{l}\text { R5. Deep analysis of } P \text { flows on the regional and } \\
\text { national levels. }\end{array}$ & $\begin{array}{l}\text { - Calculation, monitoring, and provision of reliable information on phosphorous raw } \\
\text { material flows at the NUTS } 2 \text { (Nomenclature of territorial units for statistics) minimum level. } \\
\text { - Material flow analysis (MFA) on regional and national level for each Baltic country and } \\
\text { for the entire Baltic region. }\end{array}$ \\
\hline \multirow[t]{2}{*}{ Financial support } & $\begin{array}{l}\text { R6. Financial tools supporting the sustainable } \\
\text { management, consumption and disposal of P in the } \\
\text { Baltic Sea countries. }\end{array}$ & $\begin{array}{l}\text { - CAP (Common Agricultural Policy) payments for sustainable farming practices, such as } \\
\text { direct payments for implementation of the proposed FaST Tool. } \\
\text { - Calculate the cost of pollution of water bodies (and other negative impacts) and create } \\
\text { incentive payments for avoidance. }\end{array}$ \\
\hline & $\begin{array}{l}\text { R7. Financial tools supporting research, development, } \\
\text { commercialisation, implementation and staying on the } \\
\text { market of the P-recovery technologies. }\end{array}$ & $\begin{array}{l}\text { - Conduct further research on the possibility of implementing already developed solutions } \\
\text { in all Baltic countries. } \\
\text { - Provide programs supporting investment in nutrient recovery technologies. } \\
\text { - Financial support for operating installations of P-recovery technologies. }\end{array}$ \\
\hline
\end{tabular}


Table 4. Cont.

\begin{tabular}{|c|c|c|}
\hline Category & Recommendations & Proposed Actions \\
\hline \multirow{3}{*}{$\begin{array}{l}\text { Technical and } \\
\text { environmental } \\
\text { recommendations }\end{array}$} & $\begin{array}{l}\text { R8. Improving soil and farmland management } \\
\text { practices. }\end{array}$ & $\begin{array}{l}\text { - Avoiding of erosion and increase soil carbon and microbial status by cover crops. } \\
\text { - Avoiding excessive nutrient loads through precision farming (deep knowledge on the soil } \\
\text { nutrient status and crop nutrient demand). } \\
\text { - Monitoring of farming and fertilizing practices in terms of time of fertilization, respecting } \\
\text { river strips (no fertilization zones close to water bodies), and strictly respecting health and } \\
\text { safety obligations (no sludge/manure use on crops/vegetables for consumption). }\end{array}$ \\
\hline & $\begin{array}{l}\text { R9. Identification and environmental assessment of } \\
\text { solutions dealing with P-recovery potential of different } \\
\text { waste streams and reuse. }\end{array}$ & $\begin{array}{l}\text { - Technical assessment of selected P-rich waste streams (chemical analysis, economic } \\
\text { analysis, e.g., reserves, demand, supplies, and other aspects and areas). } \\
\text { - Performance analysis of the installations across the Baltic Sea region and evaluation of } \\
\text { recycled P availability. } \\
\text { - Risk analysis to make a product that is safe for human health according to elaborated } \\
\text { national requirements (in WWTPs). } \\
\text { - Performing life cycle assessments to better understand and assess the environmental } \\
\text { impacts related to the P life cycle, both in linear and circular scenarios. }\end{array}$ \\
\hline & $\begin{array}{l}\text { R10. Development of new technologies and } \\
\text { modernization of the existing P recycling and recovery } \\
\text { technologies and solutions. }\end{array}$ & $\begin{array}{l}\text { - Further technical progress in the recovery of nutrients from various waste streams, as } \\
\text { wastewater, sewage sludge, sewage sludge ash, manure, biomass, industrial waste, bottom } \\
\text { sediments and other. } \\
\text { - Elimination of impurities, including heavy metals, presence of which in the waste } \\
\text { hampers its recycling and reuse, e.g., for fertilization purposes (due to exceeding regulatory } \\
\text { limits, e.g., for cadmium). }\end{array}$ \\
\hline \multirow[b]{2}{*}{ Social aspects } & $\begin{array}{l}\text { R11. Promoting awareness-raising among all } \\
\text { stakeholders related to P management. }\end{array}$ & $\begin{array}{l}\text { - Diffusion of knowledge about the typologies of P sources and the need/potential for } \\
\text { suitable P management, preferring circular thinking. } \\
\text { - Promotion of the alternative management systems and technological practices for a more } \\
\text { sustainable phosphorus usage among selected groups of stakeholders. }\end{array}$ \\
\hline & R12. Building a "Phosphorus Responsible Society". & $\begin{array}{l}\text { - Initiating a multi-disciplinary dialogue involving policymakers, industrial practitioners, } \\
\text { high-education institutions, researchers, farmers, and society about the consequences of } \\
\text { different P management scenarios on a global and national scale. } \\
\text { - Education of selected groups of stakeholders (farmers, companies, individuals, students) } \\
\text { on the importance of the sustainable P management. } \\
\text { - Preparation of future consumers open to accepting higher prices for products that meet } \\
\text { the requirements of a circular economy and are in the line with a "zero or low waste" strategy } \\
\text { (e.g., higher costs of the fertilizers produced from recovery and recycling of waste streams). }\end{array}$ \\
\hline
\end{tabular}




\section{Conclusions}

The holistic approach used in the InPhos project to analyze the strategic, technological, legislative, and social context for more sustainable P management in the Baltic Region made it possible to highlight that there are several opportunities to move forwards towards a circular economy in this field, but also numerous barriers. Nevertheless, urgent initiatives are necessary and have to be implemented to reduce the negative environmental impact of $P$ losses to the sea, causing eutrophication. Consequently, several recommendations have been suggested, covering different disciplines related to P management, and practical actions have been conducted in relation to social aspects (R11 and R12). With the same holistic approach, future actions starting from InPhos' results are under development to address several others of the proposed recommendations. In particular, R5-deep analysis of P flows at the regional and national levels, and R9-Identification and environmental assessment of solutions dealing with the P-recovery potential of different waste streams and environmental assessment of engineering solutions dealing with $P$ recovery and reuse will be implemented through an MFA for each involved country and through a techno-economic feasibility study for the implementation of P-recovery technologies in a real industrial setting in the Baltic region.

Author Contributions: All authors contributed equally to all aspects of the research presented in this paper. More specifically, A.B. and J.R. proposed the writing and the structure of the paper; wrote a great part of the Introduction; revised, homogenized and put together the contributions of the other authors. L.H., T.S., M.S. (Marzena Smol) and M.P. elaborated on the state-of-the-art of available technologies. All the partners belonging to the Baltic Sea Countries (M.S. (Marzena Smol), M.P., J.K., K.P. (Kastytis Pamakštys), M.K., R.O.-D., D.K., E.S., V.V., K.P. (Karin Pachel), X.Y., B.-M.S., M.S. (Magdalena Svanström) developed and summarized a deep analysis of P flows in their countries, collecting active initiatives and issues. These contributions were mainly homogenized by J.K. and K.P. (Kastytis Pamakštys). The recommendations were elaborated during the InPhos project meetings by all authors. All authors have read and agreed to the published version of the manuscript.

Funding: This research was funded by the InPhos project no. 17022 (2018-2019), which is financed by EIT Raw Materials-a body of the European Union.

Conflicts of Interest: The authors declare no conflict of interest.

\section{References}

1. Karunanithi, R.; Szogi, A.A.; Bolan, N.; Naidu, R.; Loganathan, P.; Hunt, P.G.; Vanotti, M.B.; Saint, C.P.; Ok, Y.S.; Krishnamoorthy, S. Phosphorus Recovery and Reuse from Waste Streams. In Advances in Agronomy; Elsevier: Amsterdam, The Netherlands, 2015.

2. Van Kernebeek, H.R.J.; Oosting, S.J.; van Ittersum, M.K.; Ripoll-Bosch, R.; de Boer, I.J.M. Closing the phosphorus cycle in a food system: Insights from a modelling exercise. Animal 2018, 12, 1755-1765. [CrossRef] [PubMed]

3. Cordell, D.; Cordell, D. The Story of Phosphorus: Missing Global Governance of a Critical Resource. In Proceedings of the SENSE Earth Systems Governance, Amsterdam, The Netherlands, 24-31 August 2009.

4. Cieślik, B.; Konieczka, P. A review of phosphorus recovery methods at various steps of wastewater treatment and sewage sludge management. The concept of "no solid waste generation" and analytical methods. J. Clean. Prod. 2017, 142, 1728-1740. [CrossRef]

5. Van Dijk, K.C.; Lesschen, J.P.; Oenema, O. Phosphorus flows and balances of the European Union Member States. Sci. Total Environ. 2016, 542, 1078-1093. [CrossRef] [PubMed]

6. European Commission. EU Agricultural Markets Briefs. Fertilisers in the EU Prices. Available online: https://ec.europa.eu/info/sites/info/files/food-farming-fisheries/farming/documents/market-brieffertilisers_june2019_en.pdf (accessed on 5 January 2020).

7. Zoboli, O.; Zessner, M.; Rechberger, H. Supporting phosphorus management in Austria: Potential, priorities and limitations. Sci. Total Environ. 2016, 565, 313-323. [CrossRef]

8. European Commission. Commission of European Communities. Consultative Communication on the Sustainable Use of Phosphorus. Available online: http://www.globaltraps.ch/tl_files/bilder/start/12-01-13_ Respose_to_EUSUP.pdf (accessed on 5 January 2020). 
9. European Commission. Communication from the Commission to the European Parliament, the Council, the European Economic and Social Committee and the Committee of the Regions Roadmap to a Resource Efficient Europe. Available online: https://eur-lex.europa.eu/legal-content/EN/TXT/?uri=CELEX\% 3A52011DC0571 (accessed on 3 January 2020).

10. European Commission. Commission of European Communities. Communication on the review of the list of critical raw materials for the EU and the implementation of the Raw Materials Initiative. Available online: https://op.europa.eu/en/publication-detail/-/publication/d1be1b43-e18f-11e8-b690-01aa75ed71a1/ language-en/format-PDF/source-80004733 (accessed on 23 March 2020).

11. European Commission, Commission of European Communities. Communication on the 2017 list of Critical Raw Materials for the EU. Available online: https://eur-lex.europa.eu/legal-content/EN/TXT/?uri=CELEX: 52017DC0490 (accessed on 23 March 2020).

12. European Environmental Agency (EEA). Source Apportionment of Nitrogen and Phosphorus Inputs into the Aquatic Environment; Office for Official Publications of the European Communities: Brussels, Belgium, 2005.

13. Jennings, E. Trinity College. Environmental Research Technological Development and Innovation Programme Eutrophication from Agricultural Sources: Seasonal Patterns \& Effects of Phosphorus (2000-LS-2.1.7-M2): Final Report. Available online: https://www.academia.edu/14432774/Eutrophication_from_agricultural_ sources_seasonal_patterns_and_effects_of_phosphorus (accessed on 29 December 2019).

14. Stubenrauch, J.; Garske, B.; Ekardt, F. Sustainable Land Use, Soil Protection and Phosphorus Management from a Cross-National Perspective. Sustainability 2018, 10, 1988. [CrossRef]

15. Meng, C.; Wang, Y.; Li, Y.; Zhou, J.; Li, Y.; Wu, J. Deteriorated Water Quality of Agricultural Catchments in South China by Net Anthropogenic Phosphorus Inputs. Sustainability 2017, 9, 1480. [CrossRef]

16. Selman, M.; Greenhalgh, S.; Diaz, R.; Sugg, Z. Eutrophication and Hypoxia in Coastal Areas: A Global Assessment of the State of Knowledge. World Resour. Inst. 2008, 284, 1-6.

17. Ménesguen, A.; Lacroix, G. Modelling the marine eutrophication: A review. Sci. Total Environ. 2018, 636, 339-354. [CrossRef]

18. Le Moal, M.; Gascuel-Odoux, C.; Ménesguen, A.; Souchon, Y.; Étrillard, C.; Levain, A.; Moatar, F.; Pannard, A.; Souchu, P.; Lefebvre, A.; et al. Eutrophication: A new wine in an old bottle? Sci. Total Environ. 2019, 651, 1-11. [CrossRef]

19. Ngatia, L.; Taylor, R. Phosphorus Eutrophication and Mitigation Strategies. In Phosphorus—Recovery and Recycling; Zhang, T., Ed.; IntechOpen: London, UK, 2019.

20. Selman, M.; Greenhalgh, S. Eutrophication: Policies, Actions, and Strategies to Address Nutrient Pollution. World Resour. Inst. 2009, 1-16.

21. Xu, K.-Q.; Ebie, Y.; Jimbo, Y.; Inamori, Y.; Sudo, R. Measures and Policies against the Eutrophication for Lake Water Quality in Japan. Available online: https:/pdfs.semanticscholar.org/ad77/ 1ab97ced959871570e74a2e3bea424b11a73.pdf (accessed on 12 March 2020).

22. European Court of Auditors. Combating Eutrophication in the Baltic Sea: Further and More Effective Action Needed. Available online: https://www.eca.europa.eu/en/Pages/DocItem.aspx?did=35757 (accessed on 3 January 2020).

23. HELCOM. Eutrophication in the Baltic Sea-An integrated thematic assessment of the effects of nutrient enrichment and eutrophication in the Baltic Sea region. Balt. Sea Environ. Proc. 2009, 115B, 1-152.

24. Bohman, B. Lessons from the regulatory approaches to combat eutrophication in the Baltic Sea region. Mar. Policy 2018, 98, 227-236. [CrossRef]

25. Jetoo, S. Multi-level governance innovations of the Baltic Sea and the North American Great Lakes: New actors and their roles in building adaptive capacity for eutrophication governance. Mar. Policy 2018, 98, 237-245. [CrossRef]

26. Ning, W.; Nielsen, A.B.; Ivarsson, L.N.; Jilbert, T.; Åkesson, C.M.; Slomp, C.P.; Andrén, E.; Broström, A.; Filipsson, H.L. Anthropogenic and climatic impacts on a coastal environment in the Baltic Sea over the last 1000 years. Anthropocene 2018, 21, 66-79. [CrossRef]

27. Andersen, J.H.; Axe, P.; Backer, H.; Carstensen, J.; Claussen, U.; Fleming-Lehtinen, V.; Järvinen, M.; Kaartokallio, H.; Knuuttila, S.; Korpinen, S.; et al. Getting the measure of eutrophication in the Baltic Sea: Towards improved assessment principles and methods. Biogeochemistry 2011, 106, 137-156. [CrossRef]

28. Smol, M. The use of membrane processes for the removal of phosphorus from wastewater. Desalin. Water Treat. 2018, 128, 397-406. [CrossRef] 
29. Marazzi, F.; Bellucci, M.; Rossi, S.; Fornaroli, R.; Ficara, E.; Mezzanotte, V. Outdoor pilot trial integrating a sidestream microalgae process for the treatment of centrate under non optimal climate conditions. Algal Res. 2019, 39, 101430. [CrossRef]

30. Lundberg, C. Eutrophication, risk management and sustainability. The perceptions of different stakeholders in the northern Baltic Sea. Mar. Pollut. Bull. 2013, 66, 143-150. [CrossRef]

31. Mew, M.; Steiner, G.; Geissler, B. Phosphorus Supply Chain-Scientific, Technical, and Economic Foundations: A Transdisciplinary Orientation. Sustainability 2018, 10, 1087. [CrossRef]

32. United Nations Development Programme. Human Development Index (HDI). Available online: http: //hdr.undp.org/en/indicators/137506 (accessed on 18 February 2020).

33. HELCOM. Our Baltic Sea. Available online: http://stateofthebalticsea.helcom.fi/in-brief/our-baltic-sea/ (accessed on 18 February 2020).

34. European Commission. Study on the Review of the List of Critical Raw Materials. 2017. Available online: https://op.europa.eu/s/dZ7O (accessed on 9 January 2020).

35. Lintinen, P. Selvitys Suomen Fosforipotentiaalista; Geologian Tutkimuskeskus: Rovaniemi, Finland, 2015.

36. Ahokas, K. Finland's Phosphorus Resources are More Important than Ever. Available online: http://verkkolehti.geofoorumi.fi/en/2015/10/finlands-phosphorus-resources-are-more-importantthan-ever/ (accessed on 26 January 2020).

37. Tamm, K.; Pirr, I.; Kuusik, R.; Tõnsuaadu, K. Benefication of Estonian Phosphate Ore by Flotataion. In "Beneficiation of Phosphates VIII", ECI Symposium Series, (2018). Available online: http://dc.engconfintl. org/phosphates_viii/1 (accessed on 18 February 2020).

38. Põldvere, A.; Bauert, H. Excursions Guidebook. In Proceedings of the 15th Meeting of the Association of European Geological Societies Georesources and Public Policy: Research, Management, Environment, Tallinn, Estonia, 16-20 September 2007.

39. Faure, G.; Mensing, T.M. The Estonians. The Long Road to Independence; lulu.com: London, UK, 2012.

40. Polish Geological Institute. Mineral Resources of Poland; Przenioslo, S., Ed.; Polish Geological Institute: Warsaw, Poland, 2017.

41. Balance of Mineral Resources in Poland, Polish Geological Institute-National Research Institute, Warsaw 2019. Available online: https://www.bodc.ac.uk/resources/inventories/edmed/org/609/ (accessed on 9 January 2020).

42. Andersson, M.; Carlsson, M.; Ladenberger, A.; Morris, G.; Sadeghi, M.; Uhlbäck, J. Geochemical Atlas of Sweden; Geological Survey of Sweden: Uppsala, Sweden, 2014.

43. Sveriges Geologiska Undersokning. Metaller Och Mineral i Gruvavfall. Available online: https: //www.sgu.se/mineralnaring/metall--och-mineralatervinning/metaller-och-mineral-i-gruvavfall/ (accessed on 18 February 2020).

44. Sedmalis, U.; Sperberga, I.; Sedmale, G. Classification of Latvian mineral resources. In Mineral Resources in Latvia and Their Use: With an Introduction to Mineralogy and Petrography; RTU Press: Riga, Latvia, 2002.

45. Seglins, V.; Stinkule, A.; Stinkulis, G. Phosphorite and vivianite. In Mineral Deposits of Latvia; University of Latvia Press: Riga, Latvia, 2013.

46. Knoema. World Data Atlas. Agriculture, Fertilizers, Production Quantity in Nutrients. Available online: https://knoema.com/atlas/topics/Agriculture\#Fertilizers-Production-Quantity-in-Nutrients (accessed on 18 February 2020).

47. Polish Central Statistical Office. Environment 2017 Annual Report; Statistics Poland: Warsaw, Poland, 2017.

48. Official Statistics Portal. Import of Raw Phosphorus Materials. Available online: https://osp.stat.gov.lt/ statistiniu-rodikliu-analize\#/ (accessed on 18 February 2020).

49. Food and Agriculture Organization of the United Nations. World Fertilizer Trends and Outlook to 2018; FAO: Rome, Italy, 2015.

50. Eurostat. Agri-Environmental indicator-Mineral Fertiliser Consumption. Available online: https://ec.europa.eu/eurostat/statistics-explained/index.php?title=Agri-environmental_indicator_-_ mineral_fertiliser_consumption (accessed on 18 February 2020).

51. Industrieverband Agrar, 2019. Jahresbericht 2018/2019, Frankfurt: Industrieverband Agrar e.V. Available online: https://www.iva.de/publikationen/jahresbericht-20182019 (accessed on 8 January 2020).

52. Eurostat. Livestock Density Index. Available online: https://ec.europa.eu/eurostat/web/products-datasets/-/ tai09 (accessed on 18 February 2020). 
53. Amery, F.; Schoumans, O.F. Agricultural Phosphorus Legislation in Europe. Available online: https://www.oieau.fr/eaudoc/notice/Agricultural-phosphorus-regulation-Europe-\%E2\%80\%93Experience-sharing-4-European-countries (accessed on 8 January 2020).

54. Helcom. Report on Industrial Livestock Farming in the Baltic Sea Region-Environmental Protection Context; Helcom: Helsinki, Finland, 2014.

55. Eurostat. Sewage Sludge Production and Disposal. Available online: https://ec.europa.eu/eurostat/web/ products-datasets/product?code=env_ww_spd (accessed on 18 February 2020).

56. Feature. Efficient recycling of phosphorus from sludge. Filtr. Separat. 2015, 52, 44-45. [CrossRef]

57. Vilpanen, M. Phosphorus Recovery in Finland. Case Ravita; HSY: Helsinki, Finland, 2018.

58. Pihl, T. Recovery and Reuse of Phosphorus from Municipal Wastewater-Applications and Attitudes in Finland. Master's Thesis, Submitted for Examination for the Degree of Master of Science in Technology, Aalto University. 2017. Available online: https://aaltodoc.aalto.fi/handle/123456789/29338 (accessed on 18 January 2020).

59. HSY. Viikinmäki Wastewater Treatment Plant. Available online: https:/www.hsy.fi/en/experts/water-services/ wastewater-treatment-plants/viikinmaki/Pages/default.aspx (accessed on 18 February 2020).

60. HSY. Ravita Project. Available online: https://www.hsy.fi/ravita/en/Sivut/default.aspx (accessed on 18 February 2020).

61. STN—Servicegesellschaft Tierische Nebenprodukte Mbh. 2016. Verarbeitung Tierischer Nebenprodukte. Available online: https://stn-vvtn.de/index.php (accessed on 18 February 2020).

62. Holm, O.; Thomé-Kozmiensky, E.; Quicker, P.; Kopp-Assenmacher, S. (Eds.) Verwertung von Klärschlamm 2; Thomé-Kozmiensky Verlag GmbH: Neuruppin, Germany, 2019.

63. Survey-Quality of Municipal Sewage Sludge in Latvian Water Holdings. The Plan of Developing the Proposals for Processing and Using Municipal Sewage Sludge (in Latvian); Cleantech Latvia: Riga, Latvia, 2015.

64. Report "Water-2" of the Latvian Environment, Geology and Meteorology Centre. Available online: https: //www.meteo.lv/lapas/vide/udens/notekudeni/notekudeni?id=1198\&nid=428 (accessed on 30 January 2020).

65. Cabinet Regulation No. 362, Republic of Latvia. Regulations Regarding Utilisation, Monitoring and Control of Sewage Sludge and the Compost Thereof, Adopted. Available online: https://likumi.lv/ta/id/134653noteikumi-par-notekudenu-dunu-un-to-komposta-izmantosanu-monitoringu-un-kontroli (accessed on 30 January 2020).

66. Bardule, A.; Rancane, S.; Gutmane, I.; Berzins, P.; Stesele, V.; Lazdina, D.; Bardulis, A. The effect of fertiliser type on hybrid aspen increment and seed yield of perennial grass cultivated in the agroforestry system. Agron. Res. 2013, 11, 13-24.

67. Lazdina, D.; Liepiňš, K.; Bardule, A.; Liepinšs, J.; Bardulis, A. Wood ash and wastewater sludge recycling success in fast-growing deciduous tree - Birch and alder plantations. Agron. Res. 2013, 11, 347-356.

68. Environmental Protection Agency. Wastewater Management Accounting Data. Available online: http://vanduo.gamta.lt/cms/index?rubricId=6c0feeaa-4d89-4a23-9339-19ab0de0adf1 (accessed on 18 February 2020).

69. Polish Central Statistical Office. Environmental Protection Yearbook; Statistics Poland: Warsaw, Poland, 2018.

70. Szaja, A. Phosphorus recovery from sewage sludge via pyrolysis. Ann. Set. Environ. Prot. 2013, 15, 361-370.

71. Statistics Sweden. Discharges to Water and Sewage Sludge Production in 2016. Available online: https: //www.scb.se/en/finding-statistics/statistics-by-subject-area/environment/emissions/discharges-to-waterand-sewage-sludge-production--municipal-waste-water-treatment-plants-pulp-and-paper-industryand-other-industry/pong/statistical-news/discharges-to-water-and-sewage-sludge-production-in-2016/ (accessed on 18 February 2020).

72. SOU Sustainable Sludge Handling. Report SOU 2020:3. Available online: https://www.regeringen.se/ rattsliga-dokument/statens-offentliga-utredningar/2020/01/sou-20203/ (accessed on 18 February 2020).

73. Kaikake, K.; Sekito, T.; Dote, Y. Phosphate recovery from phosphorus-rich solution obtained from chicken manure incineration ash. Waste Manag. 2009, 29, 1084-1088. [CrossRef]

74. Jin, Y.; Hu, Z.; Wen, Z. Enhancing anaerobic digestibility and phosphorus recovery of dairy manure through microwave-based thermochemical pretreatment. Water Res. 2009, 43, 3493-3502. [CrossRef]

75. Römer, W.; Steingrobe, B. Fertilizer effect of phosphorus recycling products. Sustainability 2018, 10, 1166. [CrossRef] 
76. Brod, E.; Oppen, J.; Kristoffersen, A.Ø.; Haraldsen, T.K.; Krogstad, T. Drying or anaerobic digestion of fish sludge: Nitrogen fertilisation effects and logistics. Ambio 2017, 46, 852-864. [CrossRef]

77. Hamilton, H.A.; Brod, E.; Hanserud, O.; Müller, D.B.; Brattebø, H.; Haraldsen, T.K. Recycling potential of secondary phosphorus resources as assessed by integrating substance flow analysis and plant-availability. Sci. Total Environ. 2017, 575, 1546-1555. [CrossRef]

78. Ohura, S.; Harada, H.; Biswas, B.K.; Kondo, M.; Ishikawa, S.; Kawakita, H.; Ohto, K.; Inoue, K. Phosphorus recovery from secondary effluent and side-stream liquid in a sewage treatment plant using zirconium-loaded saponified orange waste. J. Mater. Cycles Waste Manag. 2011, 13, 293-297. [CrossRef]

79. Shaddel, S.; Bakhtiary-Davijany, H.; Kabbe, C.; Dadgar, F.; Østerhus, S.W. Sustainable sewage sludge management: From current practices to emerging nutrient recovery technologies. Sustainability 2019, 11, 3435. [CrossRef]

80. Smol, M.; Adam, C.; Preisner, M. Circular economy model framework in the European water and wastewater sector. J. Mater. Cycles Waste Manag. 2020, 1-16. [CrossRef]

81. Herzel, H.; Krüger, O.; Hermann, L.; Adam, C. Sewage sludge ash-A promising secondary phosphorus source for fertilizer production. Sci. Total Environ. 2016, 542, 1136-1143. [CrossRef] [PubMed]

82. Gorazda, K.; Tarko, B.; Wzorek, Z.; Kominko, H.; Nowak, A.K.; Kulczycka, J.; Henclik, A.; Smol, M. Fertilisers production from ashes after sewage sludge combustion-A strategy towards sustainable development. Environ. Res. 2017, 154, 171-180. [CrossRef] [PubMed]

83. Schoumans, O.F.; Bouraoui, F.; Kabbe, C.; Oenema, O.; van Dijk, K.C. Phosphorus management in Europe in a changing world. Ambio 2015, 44, 180-192. [CrossRef]

84. Tan, Z.; Lagerkvist, A. Phosphorus recovery from the biomass ash: A review. Renew. Sustain. Energy Rev. 2011, 15, 3588-3602. [CrossRef]

85. El Afifi, E.M.; Hilal, M.A.; Attallah, M.F.; EL-Reefy, S.A. Characterization of phosphogypsum wastes associated with phosphoric acid and fertilizers production. J. Environ. Radioact. 2009, 100, 407-412. [CrossRef]

86. Quintana, M.; Colmenarejo, M.F.; Barrera, J.; García, G.; García, E.; Bustos, A. Use of a Byproduct of Magnesium Oxide Production To Precipitate Phosphorus and Nitrogen as Struvite from Wastewater Treatment Liquors. J. Agric. Food Chem. 2004, 52, 294-299. [CrossRef]

87. Yang, H.; Liu, J.; Hu, P.; Zou, L.; Li, Y.-Y. Carbon source and phosphorus recovery from iron-enhanced primary sludge via anaerobic fermentation and sulfate reduction: Performance and future application. Bioresour. Technol. 2019, 294, 122174. [CrossRef]

88. Zhao, Y.; Ren, Q.; Na, Y. Potential utilization of phosphorus in fly ash from industrial sewage sludge incineration with biomass. Fuel Process. Technol. 2019, 188, 16-21. [CrossRef]

89. Kraus, F.; Zamzow, M.; Conzelmann, L.; Remy, C.; Kleyböcker, A.; Seis, W.; Miehe, U.; Hermann, L.; Hermann, R.; Kabbe, C. Ökobilanzieller Vergleich der P-Einbeziehung Rückgewinnung aus dem Abwasserstrom mit der Düngemittelproduktion aus Rohphosphaten unter von Umweltfolgeschäden und deren Vermeidung, Umweltbundesamt. Texte 13/2019, Dessau-Roßlau, Februar 2019. Available online: https:// www.umweltbundesamt.de/publikationen/oekobilanzieller-vergleich-der-p-rueckgewinnung-aus (accessed on 8 January 2020).

90. Chrispim, M.C.; Scholz, M.; Nolasco, M.A. Phosphorus recovery from municipal wastewater treatment: Critical review of challenges and opportunities for developing countries. J. Environ. Manag. 2019, 248, 109268. [CrossRef]

91. Rossi, L.; Reuna, S.; Fred, T.; Heinonen, M. RAVITA Technology—new innovation for combined phosphorus and nitrogen recovery. Water Sci. Technol. 2018, 78, 2511-2517. [CrossRef] [PubMed]

92. Egle, L.; Rechberger, H.; Krampe, J.; Zessner, M. Phosphorus recovery from municipal wastewater: An integrated comparative technological, environmental and economic assessment of P recovery technologies. Sci. Total Environ. 2016, 571, 522-542. [CrossRef] [PubMed]

93. Wong, P.Y.; Cheng, K.Y.; Kaksonen, A.H.; Sutton, D.C.; Ginige, M.P. A novel post denitrification configuration for phosphorus recovery using polyphosphate accumulating organisms. Water Res. 2013, 47, 6488-6495. [CrossRef] [PubMed]

94. Mehta, C.M.; Khunjar, W.O.; Nguyen, V.; Tait, S.; Batstone, D.J. Technologies to Recover Nutrients from Waste Streams: A Critical Review. Crit. Rev. Environ. Sci. Technol. 2015, 45, 385-427. [CrossRef] 
95. Nättorp, A.; Kabbe, C.; Matsubae, K.; Ohtake, H. Development of Phosphorus Recycling in Europe and Japan BT-Phosphorus Recovery and Recycling; Ohtake, H., Tsuneda, S., Eds.; Springer: Singapore, 2019.

96. Oleszkiewicz, J.; Kruk, D.J.; Devlin, T.; Lashkarizadeh, M.; Yuan, Q. Options for Improved Nutrient Removal and Recovery from Municipal Wastewater in the Canadian Context. Environ. Technol. 2015, 20, 681-695.

97. Kabbe, C. Overview of phosphorus recovery from the wastewater stream facilities operating or under construction. In Phosphorus Recovery and Recycling; Springer: Berlin/Heidelberg, Germany, 2017.

98. European Commission. Commission of European Communities. Communication. Towards A Circular Economy: A Zero Waste Programme for Europe (COM no. 398). Available online: https://www.researchgate.net/publication/328682998_Towards_a_Circular_Economy-_a_Zero_ Waste_Programme_for_Europe (accessed on 16 February 2020).

(C) 2020 by the authors. Licensee MDPI, Basel, Switzerland. This article is an open access article distributed under the terms and conditions of the Creative Commons Attribution (CC BY) license (http://creativecommons.org/licenses/by/4.0/). 